\title{
DESIGN THINKING KAO POSLOVNI KONCEPT I ALAT U UPRAVLJANJU KNJIŽNICAMA
}

\author{
DESIGN THINKING AS A BUSINESS \\ CONCEPT AND A LIBRARY MANAGEMENT TOOL
}

\author{
Dijana Sabolović-Krajina \\ Gradska knjižnica i čitaonica „Fran Galović“ Koprivnica \\ dijana@knjiznica-koprivnica.hr
}

\author{
UDK / UDC 021:005:[303:001.8] \\ Pregledni rad / Review paper \\ Primljeno / Received: 18. 11. 2019. \\ Prihvaćeno / Accepted: 18. 2. 2020.
}

\section{Sažetak}

Cilj/svrha. Cilj je rada skrenuti pozornost hrvatske knjižničarske zajednice na design thinking kao koncept, skup metoda i alata za rješavanje poslovnih problema i uvođenje inovacija u poslovanje. Svrha je rada zainteresirati hrvatske knjižničare za usvajanje vještina i kompetencija za primjenu koncepta design thinking kako bi unaprijedili rad knjižnica i ojačali svoju poziciju u društvu. Design thinking ima temelj u metodologiji preuzetoj iz dizajna kao teorijske i praktične discipline. Ključna su mu načela usmjerenost na korisnike i strategija suradničkog rješavanja problema. Iako se počeo razvijati šezdesetih godina prošlog stoljeća integrirajući mnoge alate i tehnike iz područja kreativnosti, društvenih znanosti i računalnih znanosti, tek u proteklih nekoliko desetljeća postao je širom prihvaćen prije svega u profitnom sektoru, da bi u knjižničarski diskurs ušao prije desetak godina. Premda ne postoji konsenzus u prihvaćenosti design thinking metode u teoriji i praksi, u svijetu raste broj profitnih i neprofitnih organizacija, uključujući i knjižnice svih vrsta i veličina, koje u svom poslovanju primjenjuju metodologiju i alate koncepta design thinking.

Pristup/metodologija. Koristit će se desk research metoda. Na temelju odabira relevantne literature dat će se uvid u osnovne značajke design thinking koncepta i metoda. Iznijet će se primjeri njegove primjene u profitnom sektoru, a potom u knjižnicama kao primjeru neprofitnog sektora.

Vjesnik bibliotekara Hrvatske 63, 1-2(2020), 65-82 ISSN 0507-1925 
Rezultati. Uvidi do kojih se došlo u radu poboljšat će obaviještenost hrvatske knjižničarske zajednice o design thinking konceptu kao jednom od popularnih trendova u inovativnom i kreativnom pristupu rješavanju poslovnih problema u suvremenom upravljanju knjižnicama.

Praktična primjena. Uvid $\mathrm{u}$ teorijska načela metode design thinking i korake u procesu njegove primjene te nekoliko primjera dobre prakse mogu usmjeriti i potaknuti hrvatske knjižničare na uvođenje tih novih metoda i alata u svoje poslovanje i upravljanje knjižnicama.

Originalnost/vrijednost. Ovim se radom u teorijski diskurs u Hrvatskoj prvi put uvodi tema o konceptu design thinking kao poslovnom konceptu i alatu u knjižničnom menadžmentu.

Ključne riječi: design thinking, inovativnost, knjižnice, knjižnični menadžment

\begin{abstract}
Aim/purpose. The aim of the paper is to draw the attention of the Croatian library community to design thinking as a concept, a set of methods and tools for solving problems and introducing innovations into business. The purpose is to inspire Croatian librarians to acquire design thinking skills and competencies in order to enhance their work. It is based on the methodology taken from design as a theoretical and practical discipline. Its key principles are user focus and a collaborative problem-solving strategy. Although design thinking has been developed since 1960s, integrating many tools and techniques in the fields of creativity, social sciences and computer sciences, it has become widely accepted in recent decades, primarily in the profit sector. It entered the library discourse only ten years ago. Despite the fact that there is no consensus on its acceptance in theory and practice, there is a growing number of profit and non-profit organizations, including libraries of all types and sizes that apply methodology and design thinking tools in their businesses.
\end{abstract}

Approach/methodology. The desk research method will be used. A selection of relevant literature will provide an insight into the basic features of the design thinking concept and methods. The examples of its application in the profit sector and then in libraries, as an example of the non-profit sector, will be presented.

The results. The insights presented in the paper will improve the awareness of the Croatian library community about design thinking as one of the popular trends in innovative and creative approaches to solving business problems in contemporary library management.

Practical implications. The insights into the theoretical principles of design thinking and steps in its application, as well as several examples of good practice, could encourage Croatian librarians to introduce these new methods and tools into their libraries and library management. 
Originality/value. This paper introduces the topic of design thinking as a business concept and library management tool into theoretical discourse in Croatia.

Keywords: design thinking, innovation, libraries, library management

\section{Uvod}

U okviru diskursa o novim poslovnim modelima design thinking ${ }^{1}$ (dizajnersko razmišljanje, dizajnerski pristup, suradničko dizajniranje, dizajn usmjeren korisnicima) ima istaknuto mjesto. Design thinking je kao koncept skup metoda i alata za rješavanje poslovnih problema postao širom prihvaćen tek proteklih nekoliko desetljeća. Najveće zasluge pripisuju se američkoj savjetodavnoj i dizajnerskoj tvrtki IDEO, osnovanoj 1991. godine i njezinim osnivačima Davidu i Tomu Kelleyu, kao i njihovoj suradnji sa Sveučilištem Stanford. Velikoj popularizaciji doprinijela je i primjena koncepta design thinking u rješavanju poslovnih problema i uvođenju inovacija u proizvodima i uslugama globalnih korporacija poput Googlea, Applea, Airbnba itd. ${ }^{2}$

Od 1990-ih godina u mnogim zemljama svijeta osnivaju se škole metoda i pravaca design thinking, koji se predaje i na poslovnim školama i sveučilišnim studijima, najčešće kao dio područja upravljanja ljudskim potencijalima.

Međutim, design thinking nije novost. Počeo se razvijati još šezdesetih godina prošlog stoljeća da bi u proteklim desetljećima integrirao mnoge alate i tehnike iz područja kreativnosti, društvenih znanosti i računalnih znanosti.

Iako primjena metodologije design thinking pokazuje rezultate u praksi, ne postoji opći konsenzus u njezinom prihvaćanju, kako u krugovima znanstvenika tako i praktičara. Kao što ukazuju Vedran Antoljak i Miroslav Kosović, promotori primjene koncepta design thinking u Hrvatskoj i široj regiji, u svojoj knjizi Design thinking za nedizajnere: kako riješiti poslovne probleme i uspješno inovirati ${ }^{3}$ ne slažu se svi s korisnošću i učinkovitošću metodologije design thinking. Navode da „neki autori idu toliko daleko da design thinking smatraju potpuno beskorisnim, neuspješnim i nesuvislim, pritom se koristeći pogrdama poput novog mita, budalaštine ili novog pokusa“". ${ }^{4}$

\footnotetext{
1 Budući da u tekstovima i radovima na hrvatskom jeziku nema konsenzusa o prijevodu termina design thinking, $\mathrm{u}$ ovom se radu termin koristi u izvornom, engleskom obliku, kao što se koristi i u prvoj knjizi o toj problematici, koju su napisali hrvatski autori na hrvatskom jeziku. Usp. Antoljak, V.; M. Kosović. Design thinking za nedizajnere: kako riješiti poslovne probleme i uspješno inovirati. Zagreb: Školska knjiga: Sense savjetovanja, 2018.

2 Antoljak,V. ; M. Kosović. Nav. dj., str. 16.

3 Isto, str. 45-55.

4 Isto, str. 26.
} 


\section{Definicija i osnovna načela koncepta design thinking}

Kao relativno novi poslovni koncept i metodološki alat design thinking nema jedinstvenu definiciju. Antoljak i Kosović daju svoju, kako je nazivaju, pragmatičnu definiciju koncepta design tkinking kao načina rješavanja nekog problema pomoću strukturiranog procesa te skupa metoda i tehnika koje izvorno potječu iz dizajna kao praktične i teorijske discipline. ${ }^{5}$ Ističu tri glavna definicijska smjera koncepta design thinking s obzirom na to gdje i kako se taj koncept koristi (podjednako teoretskim i praktičnim situacijama i koje se značenje daje konceptu) - kao dizajn i razvoj inovacija kako ga vidi tvrtka IDEO; kao metodu rješavanja složenih organizacijskih problema i poslova te vještina potrebna menadžmentu; kao dio šire teorije menadžmenta. ${ }^{6}$

Temelj koncepta design thinking čini metodologija preuzeta iz dizajna. Dizajn kao znanstvena disciplina temelji se na objektivnom, strukturiranom i racionalnom postupku. Polazi od hipoteza koje se testiraju i prilagođavaju shodno terenskim nalazima. ${ }^{7}$ Koristi se različitim empirijskim metodama poput promatranja subjekta, simulacije uvjeta, konteksta i iskustva, potom eksperimentiranja, izlaganja subjekta različitim varijablama, prototipiziranja različitog stupnja vjernosti i $\mathrm{dr}^{8}$

Ključno je načelo kvalitetnog dizajna usmjerenost na korisnike, njihove emocionalne potrebe i ponašanja. Korisnika se nastoji uključiti u sve analitičke i stvaralačke faze nastanka nekog proizvoda ili usluge. Osnovni pristup dizajna usmjerenog čovjeku ili humanog dizajna (engl. human-centered design) jest razvijanje empatije, tj. duboko shvaćanje ljudskog ponašanja. Na taj način stvara se osnova za prikupljanje potencijalnih rješenja problema. ${ }^{9}$

Vrlo je važno načelo koncepta design thinking i strategija zajedničkog stvaranja ili tzv. participativni dizajn. Takvim pristupom uključuje se potencijalne korisnike u inovacijske aktivnosti organizacije. Potiče ih se da svojom kreativnošću doprinesu rješavanju poslovnih problema ili pokretanju nove ponude proizvoda ili usluga. ${ }^{10}$

\section{Primjena koncepta design thinking u profitnom sektoru}

Design thinking kao poslovni koncept i alat u upravljanju vezan je primarno uz komercijalni, profitni poslovni sektor. Vedran Antoljak i Miroslav Kosović ističu

\footnotetext{
5 Isto, str. 29. Antoljak,V.; M. Kosović. Nav. dj. str. 26.

7 Antoljak,V.; M. Kosović. Nav. dj., str. 19.

8 Isto.

9 Isto, str. 20.

10 Isto.
}

${ }_{6}$ Johannsen- Sköldberg, U.; J. Woodila; M. Çetinkaya. Design thinking: past, present and possible futures. // Creativity and Inovation Management 22(2013), 121-146. Citirano prema: 
kako su mnoge inovacije u različitim poslovnim područjima nastale upravo primjenom koncepta design thinking. ${ }^{11}$ Navode primjer stvaranja prvog računalnog miša suradnjom računalne kompanije Apple i dizajnerske i savjetodavne tvrtke IDEO. Primjer primjene metode design thinking jest i suradnja Bank of America i tvrtke IDEO u osmišljavanju programa štednje koji je mnoge Amerikance potaknuo da otvore štedni račun. Primjena metoda design thinking transformirala je i poslovanje Airbnba, tvrtke koja se bavi posredovanjem u iznajmljivanju stanova, tako što je postala svjetski lider u poticanju ljudi da otvore svoje domove potpunim strancima. Kao uspješan primjer primjene koncepta i metoda design thinking ističe se i stvaranje novog iskustva gostiju lanca hotela Starwood, kojemu pripadaju marke poput Sheratona i Westina, i to osmišljavanjem sustava digitalne prijave gostiju kako bi izgubili što manje vremena. Navodi se i primjer osmišljavanja proizvoda društvene organizacije Embrace, jeftinog ručnog ,inkubatora“ od posebnog materijala kojim su spašeni mnogobrojni životi novorođenčadi u siromašnim zemljama Trećeg svijeta. Primjenom koncepta i metoda design thinking riješen je i problem organizacije General Electric Healthcare, konkretno uklanjanje straha od bolnice i pregleda CT-om, rendgenom i magnetskom rezonancijom kod velikog broja djece - osmišljene su spavaće vreće iz kojih djeca tijekom pregleda promatraju nebeski zvjezdani svod oslikan na stropu. Globalno poznata Coca Cola željela je povećati zadovoljstvo i napredak u produktivnosti svojih zaposlenika. Koristeći dizajnerske tehnike poput tehnike vizualizacije iskustva korisnika (engl. journey mapping), izrade prototipa i sl., u suradnji tima dizajnera i odjela za ljudske potencijale osmišljeni su novi digitalni, mobilni i komunikacijski alati koji su povećali produktivnost i zadovoljstvo zaposlenika u radu.

Navedeni primjeri ukazuju da se pristup design thinking uvodi u profitni sektor kao novi koncept $i$ alat uz tradicionalne modele poslovanja i upravljanja. Antoljak i Kosović ističu osnovnu razliku između tih dvaju pristupa - poslovnog i dizajnerskog. Dok je poslovni pristup vođen racionalnošću i objektivnošću, ekonomskom logikom i kvantificiranjem, dizajnerski pristup vođen je ljudskim iskustvom, donošenje odluka pokreće emocije više nego logika, a htijenje se smatra snažnijim motivatorom od razuma. ${ }^{12}$ Dok menadžeri rješenja temelje na analizi podataka, dizajneri su usredotočeni na potrošačko iskustvo. Dok menadžeri radije biraju precizno planiranje i pri tome se koriste tehnikama i metodama poput proračunskih tablica i tržišnih analiza, preciznim poslovnim softverima i sl., dizajnerski pristup radije bira eksperimentiranje. Dizajneri koriste ponavljanje procesa, tzv. iteraciju i stvaranje prototipova kako bi došli do što boljih odgovora. ${ }^{13}$

Razloge primjene metoda dizajna u profitnom poslovnom svijetu, posve drugačijem od dizajnerskog, Antoljak i Kosović objašnjavaju činjenicom da oslanja-

\footnotetext{
11 Isto, str. 45-55.

12 Isto, str. 58.

13 Isto, str. 59.
} 
nje na tradicionalne poslovne modele i monolitne strukture više nije učinkovita poslovna strategija zbog brzih promjena, poslovnih tektonskih poremećaja, neizvjesnosti i diskontinuiteta u užem i širem društvenom okruženju. ${ }^{14}$ Presudnu ulogu na brze promjene u poslovnom svijetu ima informacijsko-komunikacijska tehnologija. Brzi tehnološki razvoj utječe na potrebu brzog prilagođavanja tržišsnoj utakmici. Dizajnerski pristup pokazao se uspješnim alatom u suočavanju sa složenim poslovnim izazovima, kao što ukazuju i prethodno spomenuti primjeri njegove primjene - bilo da se radi o razvijanju prilagodljivih poslovnih strategija, stvaranju održive diverzifikacije, razvijanju kulture inovativnosti, zbližavanju s korisnicima i zaposlenicima, prilagođavanju tehnološkim disrupcijama i dr. ${ }^{15}$

\section{Primjena koncepta design thinking u knjižnicama}

Brze društvene, ekonomske, političke, kulturne, tehnološke i socijalne promjene u užem i širem društvenom okruženju utječu na potrebu uvođenja novih poslovnih koncepata, metoda i alata i u neprofitni sektor.

Iako su se koncept, metode i alati design thinking u početku koristili za razvoj inovativnih rješenja za proizvode i usluge u komercijalnom sektoru, $\mathrm{s}$ vremenom su se počeli primjenjivati i za rješavanje poslovnih problema u neprofitnom sektoru, pa tako i u knjižničarstvu, konkretno u redefiniranju zadaća i uloga knjižnica u suvremenom, informacijskom društvu. Design thinking nudi s jedne strane novu perspektivu, nove alate i nove pristupe za otkrivanje što zajednice i korisnici pojedinih knjižnica žele, a s druge strane metodu eksperimentiranja u stvaranju novih usluga, programa i poslovnih procesa kako bi se zadovoljile potrebe u promjenjivom okruženju.

Jennifer A. Bartlett u članku Design Thinking in Libraries ${ }^{16}$ ukazuje da se primjena dizajnerskog razmišljanja u knjižničarstvu prvo povezuje s akademskim knjižnicama. Navodi da rani uvod u pristup design thinking u knjižnicama predstavlja knjiga Stevena J. Bella i D. Shanka Academic Librarianship by Design: A Blended Librarian's Guide to the Tools and Techniques. Ti autori naglašavaju potrebu razvijanja „kombiniranog“ knjižničarskog seta vještina koji bi povezivao tradicionalna knjižničarska znanja s vještinama i sposobnošću da se tehnologija odgovarajuće primijeni u podučavanju i učenju korisnika te da se primijene principi koncepta design thinking na razvoj knjižničnih usluga. Bell i Shank smatraju da knjižnice bilo koje vrste riskiraju zastarijevanje ako ne reagiraju na potrebe svojih korisnika. Aktivno uključivanje profesora i studenata u rasprave o tome što žele i trebaju od svojih knjižnica stoga je neophodno. Za postizanje tog cilja autori

14 Isto, str. 60

15 Isto, str. 61.

16 Bartlett, J. A. Design thinking in libraries. // Library Leadership \& Management 34, 4(2018), 1-6. [citirano: 2019-11-15]. Dostupno na: https://uknowledge.uky.edu/libraries_facpub/297. 
zagovaraju primjenu koncepta design thinking kao načina pružanja usluga i uputa zasnovanih na otkrivanju načina razmišljanja korisnika knjižnice i onoga što im predstavlja idealno iskustvo u knjižnici.

Popularizacija primjene koncepta i alata design thinking u narodnim knjižnicama u svijetu pripisuje se Knjižnicama grada Aarhusa, drugog po veličini grada u Danskoj. Činjenica da poticaj za primjenu koncepta design thinking u narodnim knjižnicama dolazi iz jedne skandinavske zemlje može se povezati i s poviješću dizajna, konkretno s pojavom tzv. skandinavskog suradničkog dizajniranja u pedesetim i šezdesetim godinama prošlog stoljeća. Suradničko dizajniranje zasniva se kako na skandinavskoj tradiciji sudjelovanja običnih ljudi u raspravama i odlukama o različitim područjima života tako i na pozivanju običnih ljudi, a ne samo stručnjaka, u raspravu o dizajnu, u stvaranje prototipova i otvorenog razgovora o novim idejama ili poboljšanju radnih procesa. ${ }^{17}$

Knjižnice grada Aarhusa surađivale su s Gradskom knjižnicom u Chicagu na projektu koji je financirala Fondacija Bill and Melinda Gates u okviru programa Global Libraries tijekom 2013. i 2014. godine. Cilj projekta bio je popularizirati i promovirati design thinking kao novi način poslovanja koji knjižnicama nudi pomoć u razumijevanju potreba knjižničnih korisnika i lokalnih zajednica. Rezultat je projekta priručnik čiju je izradu vodila već spomenuta, globalno poznata savjetodavna tvrtka i dizajnerski studio IDEO, rukovodeći se iskustvom rada $\mathrm{s}$ knjižničarima u njihovom svakodnevnom profesionalnom okruženju. Uz suradnju s knjižnicama u Aarhusu i Chicagu, promatrali su rad više od četrdeset knjižničara iz deset zemalja te svoja saznanja sintetizirali u priručnik pod nazivom Design thinking for libraries. Publikacija se sastoji od triju dijelova: Design Thinking for Libraries: a Toolkit for Patron-centered Design ${ }^{18}$ Activities Workbook ${ }^{19}$ i Design Thinking in a Day: an at-a-glance Guide for Advancing your Library. ${ }^{20}$

Navedeni priručnik pruža knjižničarima uvid u postupak i primjere primjene koncepta design thinking u knjižnicama. Prema riječima autora priručnik uveliko demistificira proces design thinking te knjižničarskoj zajednici daje resurse da ga lakše implementiraju u svoje organizacije i integriraju u svoju praksu. Vodi kroz proces koji dizajneri koriste za promišljeno prepoznavanje problema i zatim, pomoću timskog pristupa, razvijaju prototipove korisne za konačni izbor i implementaciju optimalnog rješenja.

\footnotetext{
17 Antoljak,V. ; M. Kosović. Nav. dj., str. 31.

18 Design thinking for libraries: a toolkit for patron-centered design. 1st ed. /San Francisco/: Ideo, 2015. [citirano: 2019-11-15]. Dostupno na: http://designthinkingforlibraries.com/.

19 Design thinking for libraries activities workbook: A toolkit for patron-centered design. 1st ed. San Francisco: Ideo, 2015. [citirano: 2019-11-15]. Dostupno na: http://designthinkingforlibraries.com/.

20 Design thinking in a day: an at-a-glance guide for advancing your library. 1st ed. /San Francisco/: Ideo, 2015. [citirano: 2019-11-15]. Dostupno na: http://designthinkingforlibraries.com/.
} 
Prema ovom priručniku, a kako je prikazano na slici 1, osnovni koraci design thinking alata u knjižnicama su INSPIRACIJA (prepoznavanje problema i otkrivanje novih perspektiva pristupu njegova rješavanja - Imam izazov. Kako da mu pristupim?), IDEACIJA (generiranje ideja za rješavanje problema i stvaranje prototipova koji ideje čine opipljivima - Nešto sam naučio. Kako to tumačiti i izraziti svoje ideje?), ITERACIJA (kontinuirano eksperimentiranje na temelju povratne informacije korisnika o predloženom rješenju problema-Imam prototip. Kako ga testirati i poboljšati u suradnji s korisnicima?).

\section{GETTING STARTED: THE DESIGN THINKING PROCESS}

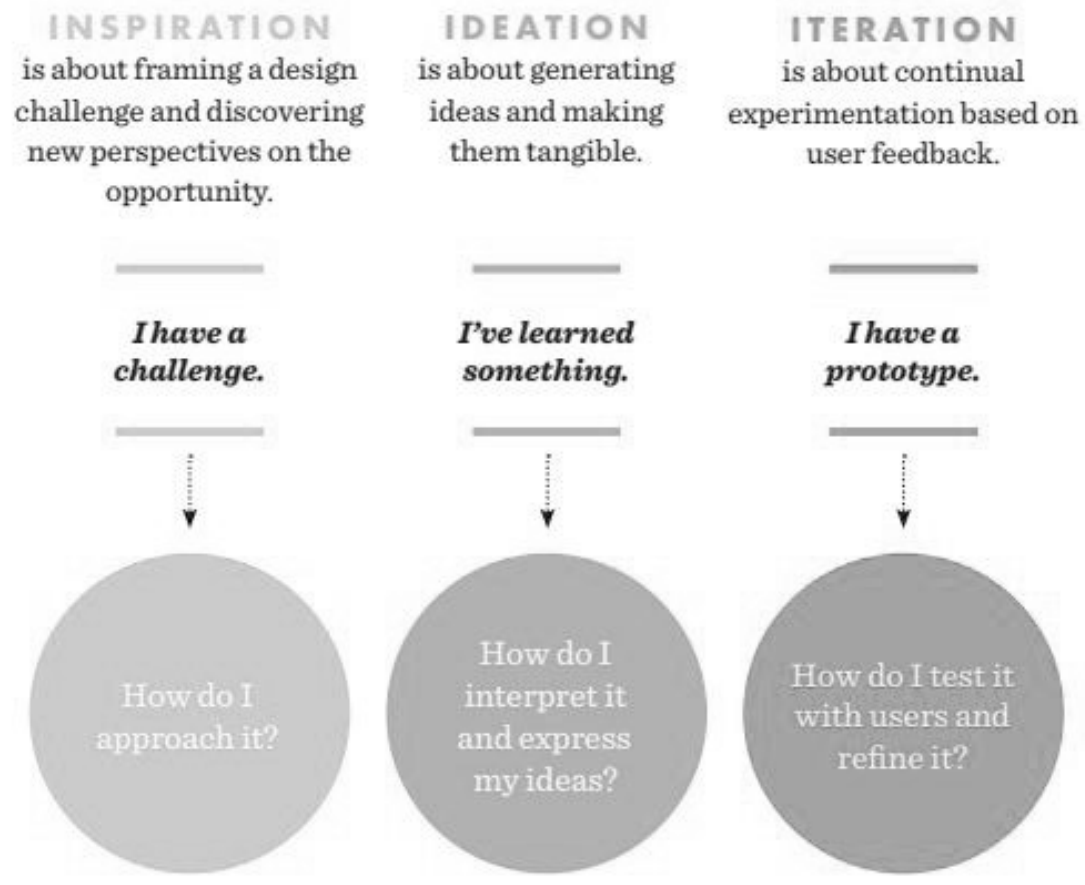

Slika 1. Koraci u procesu design thinking ${ }^{21}$

Sidsel Bech-Petersen, voditeljica Odjela za inovacije i uključivanje korisnika u Knjižnicama grada Aarhusa, ističe da su empatija i stvaranje prototipa dvije

${ }^{21}$ Design thinking for libraries: a toolkit for patron-centered design. 1st ed. San Francisco: IDEO, 2015. Str. 9. 
glavne komponente u procesu design thinking. ${ }^{22}$ Empatizirati znači staviti se $\mathrm{u}$ „cipele korisnika“, bolje ih upoznati i saznati više o njima ostavljajući po strani vlastita stajališta, interese i ciljeve. Prototipiziranje se odnosi na kontinuirano eksperimentiranje na temelju povratnih informacija korisnika. Prototip može biti izrađen od kartona, nacrtan na komadu papira ili nastati igranjem uloga. Takav pristup omogućuje da se ideje učine opipljivima i da se lakše podijele s drugima kako bi se dobile povratne informacije i saznalo kako ideju dalje razvijati. Prema Bech-Petersen knjižnice su savršeni prostori za prototipiziranje zato što ih posjećuju mnogi korisnici koji žele sudjelovati u pronalaženju rješenja problema i dati povratne informacije.

John J. Meier i Rebecca K. Miller ukazuju na korisnost tzv. brze izrade prototipa (engl. rapid prototyping) kao alata za uvođenje organizacijskih promjena $u$ knjižnicama, poput promjena u poučavanju, knjižničnom prostoru ili uslugama. ${ }^{23}$ Anksioznost zaposlenika knjižnica zbog ubrzanog tempa promjena može se ublažiti tako da ih se uključi u proces pronalaženja novih rješenja. Dizajnerskim procesima rješavanju problema pristupa se kao procesu učenja, što uključuje i pronalaženje pravog problema. Kroz sudionički proces poboljšavaju se vještine izrade i korištenja prototipova. Prototipiziranje je alat za učenje i uspostavljanje razmjene mišljenja, a uz to dopušta neuspjeh bez financijskih posljedica jer se pri tome koriste priručni materijali (papir, ljepilo, flomasteri, igranje uloga i sl.). Ako cilj nije postignut, predloženo se rješenje odbacuje. Korištenje dizajnerskog razmišljanja također uči da se ne treba usredotočiti na demografiju (spol i dob korisnika), već više na ponašanja poput korisničkih navika, rituala i rutina. Kretanje korisnika kroz knjižnični sustav često govori više o tome tko su, nego na primjer, njihova dob. Primjeni brze izrade prototipa doprinijet će sve veća raširenost 3D printera u knjižnicama.

Leuzinger, Kessler Lee i Korbe ukazuju na još jednu značajku koncepta design thinking, a to je nelinearnost koraka u procesu i iteracija (ponavljanje, eksperimentiranje). ${ }^{24}$ Na primjer, dizajner može doći do faze evaluacije predloženog rješenja (prototipa) i od korisnika dobiti negativnu povratnu informaciju. Kako bi u konačnici stvorio proizvod ili uslugu koji će najbolje zadovoljili potrebe korisnika, treba se vratiti na prethodne faze procesa design thinking. Taj je postupak poznat kao brza izrada prototipa i koristi se za prikupljanje povratnih informacija korisnika u ranim fazama procesa dizajniranja.

22 Design thinking for libraries. [citirano: 2019-11-15]. Dostupno na: https://princh.com/designthinking-for-libraries/\#.XcqKsjJ7nIU.

${ }^{23}$ Meier, J. J. ; R. K. Miller. Turning the revolution into an evolution: the case for design thinking and rapid prototyping in libraries. // College \& Research Libraries News 77, 6(2016), 283-286. [citirano: 2019-11-15]. Dostupno na: https://doi.org/10.5860/crln.77.6.9506.

24 Leuzinger, R.; G. Kessler Lee; I. Korbe. Keeping up with... design thinking. // American Library Association. [citirano: 2019-11-15]. Dostupno na: http://www.ala.org/acrl/publications/ keeping_up_with/design. 


\section{Primjeri primjene koncepta design thinking u knjižnicama}

Korištenje metoda i alata design thinking uvelike je obilježilo desetogodišnji proces osmišljavanja i planiranja nove zgrade glavne knjižnice u Aarhusu.$^{25} \mathrm{U}$ lipnju 2015. godine grad Aarhus otvorio je knjižnicu u nekadašnjem industrijskom dijelu luke pod nazivom Dokk1 kao najveću javnu knjižnicu Skandinavije. Ona predstavlja novu generaciju modernih hibridnih knjižnica uz isticanje osnovne značajke, a to je promjena paradigme i fokusa od fizičkih medija prema prostoru za ljude i međuljudske kontakte i odnose. Ta je knjižnica nagrađivana međunarodnim nagradama za arhitekturu i dizajn. ${ }^{26} \mathrm{~S}$ oko 3800 posjeta dnevno predstavlja središnje okupljalište stanovnika grada Aarhusa koji ima 330000 stanovnika. Ima površinu od $28000 \mathrm{~m}^{2}$, od čega je $18000 \mathrm{~m}^{2}$ za potrebe knjižnice i javne servise za građane, $10000 \mathrm{~m}^{2}$ za iznajmljivanje i automatizirano parkiralište za 1000 vozila. Dokk1 otvorena je sedam dana u tjednu, 82 sata tjedno, s 25 sati bez knjižničnog osoblja. ${ }^{27}$

Navedeni podaci govore o kompleksnosti projekta, a u osmišljavanju i oblikovanju prostora za raznolike programe, sastanke, učenje, stvaranje, suradnju, kontemplaciju i igru koristili su se novi pristupi u planiranju, koji su zauvijek promijenili značajke i prostor ne samo knjižnice u Aarhusu, nego i značajke knjižnica uopće. Konceptualna transformacija knjižnice osmišljavala se kroz mnogobrojne razgovore u think tanks grupama (trustovi znanja) i strateškim grupama koje je sačinjavao širok raspon ljudi iz cijelog grada. Zajedničkim promišljanjem osmišljena je vizija nove knjižnice koja se zasniva na četiri postavke - da bude prostor za suradnju, mjesto za dijalog, znanje, ideje i inspiraciju, otvoreno neformalno mjesto za učenje te jedinstveno mjesto za djecu i obitelj. ${ }^{28}$

Marie Østergård, ravnateljica Knjižnica grada Aarhusa, ističe da su ključni trenuci kroz cijeli razvoj projekta nove knjižnice Dokk1 bili primjena metodologija design thinking i participativnog dizajna s fokusom na ljude. ${ }^{29}$ Kroz cijeli proces planiranja i gradnje fokus je bio na stvaranju knjižnice za ljude, a ne za knjige te na prostor organiziran na principima ljudskih potreba. Primjenjivalo se jednostavno načelo dizajnerskog razmišljanja ,učimo od ljudi“. Fokus je bio na potrebama građana, a ne na potrebama knjižnice. Da bi to zaista bio projekt u skladu sa

\footnotetext{
25 Østergård, M. Dokk1 - Re-inventing space praxis: a mash-up library, a democratic space, a sity lounge or a space for diversity? // Library design for the 21st century: collaborative strategies to ensure success / ed. by Koen, Diane, Lesneski, Traci Engel. Berlin; Boston: De Gruyter Sauer, 2019. Str. 91-103.

26 Rum til forandring - Dokk1- Aarhus 'nye mødested = Space for change : Dokk1 - Aarhus new meeting place redaktions gruppe / editorial board Rolf Hapel, Knud Schulz, Marie Østergard, Kim Holst Jensen. Aarhus: Aarhus Kommunes Biblioteker, 2015.

27 Østergård, M. Nav. dj., str. 91.

28 Isto, str. 93.

29 Isto, str. 96-97.
} 
zacrtanim knjižničnim konceptom i potrebama lokalne zajednice, znanje je trebalo doći iz različitih područja. Stoga je tisuće građana, političara, stručnjaka, knjižničara, učenika, studenata, arhitekata i inženjera bilo izravno uključeno u razvoj Dokk1. Da bi se sakupilo što više informacija i znanja od korisnika, radilo se u dvije paralelne linije uključivanja korisnika u planiranje nove knjižnične zgrade. Prva linija uključivanja korisnika bila je vezana za tzv. transformation lab, prostor u središnjem holu stare knjižnice, gdje su se prototipizirale i testirale usluge, namještaj i ideje za Dokk1. Druga linija razvoja i uključivanja u proces građenja uključivala je rad korisnika, inženjera i arhitekata na razvoju rješenja za akustiku, svjetlo i prostornu signalizaciju.

Østergård ističe da iskustvo projektiranja i gradnje nove knjižnice u Aarhusu pokazuje da primjena metoda design thinking u radu i razvoju knjižnica ne poboljšava samo njihovu kvalitetu nego utječe i na zajedničko vlasništvo zajednice nad knjižnicom i njezinim prostorom. ${ }^{30} \mathrm{~S}$ fleksibilnošću prostora koja omogućuje stalne promjene i nove društvene potrebe u razvoju zajednice knjižnica, Dokk1 je primjer društvene održivosti jer je svojom ponudom otvorena svim dobnim, socijalnim, profesionalnim i obrazovnim skupinama.

Uključivanjem korisnika i primjenom metoda i alata design thinking Knjižnice grada Aarhusa transformirale su ne samo knjižničnu zgradu nego i knjižničnu kulturu i model poslovanja. Koriste ih u rješavanju svakodnevnih izazova u knjižnici te za razvoj boljih programa, usluga i rasporeda prostora u knjižnici.

Tako je tim knjižničara iz ogranka Aaby Knjižnica grada Aarhusa primijenio alate design thinking na projektu izgradnje povjerenja s lokalnim tinejdžerima. ${ }^{31}$ Nedolazak tinejdžera u knjižnicu prepoznat je kao hitan problem. Knjižničari su krenuli od hipoteza („Mladim je ljudima knjižnica dosadna“, „,Tinejdžeri su previše hiperaktivni da bi pronašli nešto atraktivno u knjižnici“, „Knjižnične aktivnosti nisu dovoljno funky"). Da bi zaista upoznali lokalne tinejdžere, proveli su više radionica u njihovim školama i klubovima, gdje su razgovarali o tome što knjižnice znače za njih i društvo i što bi knjižnice mogle učiniti da budu relevantne u njihovim životima. Knjižničari su saznali od tinejdžera mnogo toga što nisu sami znali, ali najvažnije je bilo da se ne osjećaju dobrodošlo niti ugodno u knjižnici.

Nakon što je uočen pravi problem, knjižničari su u nizu novih radionica koristili metodu brainstorming ${ }^{32} \mathrm{~s}$ ciljem uključivanja lokalnih tinejdžera u pretva-

\footnotetext{
30 Isto, str. 98.
}

31 A branch library builds trust with local teens. [citirano: 2019-11-15]. Dostupno na: http:// designthinkingforlibraries.com/teens.

32 Oluja mozgova (engl. brainstorming) postupak je koji se koristi za pronalaženje rješenja određenoga problema, načina postizanja nekoga cilja ili za razumijevanje problema. Sastoji se od iznošenja ideja i rješenja tijekom grupne rasprave. U početnoj fazi (tzv. zeleno svjetlo) iznose se ideje, ali bez kritike ili vrjednovanja, a u idućoj se fazi (tzv. crveno svjetlo) predložena rješenja 
ranje knjižnice u mjesto gdje se osjećaju ugodno. To je rezultiralo s više od sto ideja kako raditi s tinejdžerima. Odabrali su deset koncepata i tražili tinejdžere da glasaju za najbolji. U glasanju je sudjelovalo $80 \%$ svih učenika osmih razreda u Aarhusu. Pobijedila je ideja pod nazivom Čokoladni kutak - kutak knjižnice s odabranim namještajem, društvenim igrama, Play Stationom, električnim čajnikom, šalicama i vrućim kakaom. Tinejdžeri su pomagali ukrašavanjem i odabirom namještaja te se aktivno uključili u oblikovanje prostora. Vrijednost ugodnog kutka s vrućom čokoladom jest stvaranje osjećaja da je prostor njihov i da u knjižnici imaju nešto što su sami odabrali i u čemu mogu zajedno uživati. Knjižničari su postigli željeni cilj - sada je knjižnica, a posebno taj prostor, preplavljena tinejdžerima, a osobito u Čokoladni utorak i četvrtak. A tu je i učinak na mnoštvo drugih građana koji uživaju u Čokoladnom kutku na raznim sastancima i drugim programima knjižnice.

Uz taj slučaj dobre prakse na mrežnoj stranici projekta Design thinking for libraries $^{33}$ mogu se pregledati videozapisi i pročitati priče iz cijelog svijeta koje predstavljaju primjere dizajnerskog razmišljanja u knjižnicama. Tako primjer regionalne knjižnice Sulzer u Chicagu u stvaranju projekta Culture of yes, kao odgovora na suočavanje s financijskim i kadrovskim izazovima, predstavlja način razmišljanja koji je bitan dio primjene koncepta design thinking u izgradnji inovativne organizacijske kulture. Design thinking kao novi način razmišljanja i razvoj novih alata koristili su knjižničari u Italiji, Portugalu, Rumunjskoj, Brazilu. Narodna knjižnica u Šangaju koristila je priručnik Design Thinking for Libraries za redizajn korisničkih površina u svojoj knjižnici.

U dostupnoj literaturi nalazimo primjer američke narodne knjižnice Hillsboro. ${ }^{34} \mathrm{Za}$ razvoj novog modela usluga i suradnje usmjerenih na korisnike ta je knjižnica slijedila sedam koraka u procesu design thinking kako su prvi put predloženi u knjizi Herberta Simona iz 1969. godine The Sciences of the Artificial. Ti koraci su: Definiranje, Istraživanje, Ideacija, Prototipiziranje, Odabir, Implementacija i Naučeno. Cilj projekta bio je smanjiti broj informacijskih punktova i olakšati korisnicima dobivanje kvalitetne pomoći. U cjelodnevnoj radionici, koju je vodio vanjski moderator, također su se koristili priručnikom Design Thinking for Libraries, započevši s brzim upoznavanjem procesa de-

kritički ocjenjuju i vrednuju. Taj postupak, premda popularan, rezultira manjim brojem ideja kada se provodi u grupi (može doći do pojave sugestije) nego kada se primjenjuje pojedinačno. Usp. Oluja mozgova: enciklopedijski članak. // On-line izdanje Hrvatske enciklopedije Leksikografskog zavoda Miroslav Krleža. [citirano: 2020-01-15]. Dostupno na: http://www.enciklopedija.hr/ natuknica.aspx? ID $=45089$.

33 Design thinking for libraries: examples. [citirano: 2019-11-15]. Dostupno na: http:// designthinkingforlibraries.com/examples

${ }^{34}$ Chase, S. Design thinking in action: changing the public service model. // OLA Quarterly 22, 3(2017), 15-19. [citirano: 2019-11-15]. Dostupno na: https://commons.pacificu.edu/cgi/ viewcontent. cgi article $=1865 \&$ context $=$ olaq . 
sign thinking, kao i uvodnim vježbama za kreativno razmišljaju o problemu. Nakon te vježbe otvaranja, prešli su na glavni zadatak dana, a to je kretanje kroz proces dizajnerskog razmišljanja s pitanjem: Kako bismo mogli stvoriti model suradničke usluge na prvom katu knjižnice u Brookwoodu? Dan su proveli usavršavajući definiciju problema. Umjesto da model usluge postave kao problem, fokus su stavili na istraživanje načina kako poboljšati iskustvo korisnika i donijeti veće zadovoljstvo knjižničnom osoblju. To su učinili raznim vježbama, istražujući trenutne prepreke u konfiguraciji informacijskih deskova. Istraživanje su proveli promatrajući u stvarnom vremenu ponašanje korisnika knjižnice. Izrađivali su prototipove razmještaja informacijskih punktova i postavljali ih u prostor. U proces su uključili i korisnike volontere. Njihove ideje pomogle su ne samo u boljem rasporedu strojeva za samoposluživanje nego i u većoj vidljivosti knjižničnog osoblja koje odgovara na informacijske upite stavljanjem bedževa ili majica s natpisom Pitaj me. Iako im se koncept design thinking učinio prezahtjevnim, ipak su se kroz taj postupak osvjedočili da je to učinkovito sredstvo za uključivanje osoblja u definiranje pravog problema te zajedničko sudjelovanje u kreativnom rješavanju problema kako bi se postigli željeni rezultati.

Kako integrirati dizajnersko razmišljanje u knjižnične aktivnosti za mlade, odnosno kako umjesto zadavanja aktivnosti mladima pružiti okvir za razmišljanje o aktivnostima objašnjava L. W. Braun. ${ }^{35}$ Iako se koraci u dizajnerskom razmišljanju mogu razlikovati ovisno o točnom modelu koji koristite, osnovni tijek sljedeći je:

1. Odlučite koji problem treba riješiti (ta odluka može se donijeti čitanjem, razgovorom ili promatranjem).

2. Provedite vrijeme učeći o problemu dodatnim istraživanjima, razgovorima i promatranjem. 3. Primijenite brainstorming u traženju rješenja problema.

4. Razvijte prototipove potencijalnih rješenja.

5. Ispitajte prototipove.

6. Ponovite faze prototipiziranja i ispitivanja.

Rezultat je tog procesa pomoć mladima u razvijanju vještina poput kritičkog razmišljanja, rješavanja problema, suradnje, pripreme za daljnje školovanje i karijeru te socijalno i emocionalno učenje koje proizlazi iz razumijevanja tuđe potrebe (ulaženje u „tuđe cipele“ ili „tuđu kožu“). Dizajnersko razmišljanje ta-

35 Braun, L. W. Using design thinking: providing a framework for youth activities. // American libraries, May 31,2016. [citirano: 2019-11-15]. Dostupno na: https://americanlibrariesmagazine. org/2016/05/31/using-design-thinking/. 
kođer može podržati vještinu informacijske pismenosti jer mladi mogu sudjelovati $\mathrm{u}$ istraživačkim aktivnostima kao dijelu cjelokupnog procesa.

\section{Design thinking u Hrvatskoj i hrvatskom knjižničarstvu}

Unatrag nekoliko godina design thinking se u Hrvatskoj poučava na radionicama i seminarima pojedinih konzultantskih tvrtki, a neke od njih promoviraju ga na portalima u člancima svojih predavača. ${ }^{36} \mathrm{U}$ okviru znanstvenog diskursa postoje malobrojni članci, a jedan od njih problematizira design thinking kao novi upravljački pristup koji se još uvijek ne primjenjuje dovoljno kao predmet u obrazovnim programima hrvatskih poslovnih škola i sveučilišta, iako su njegove prednosti u poslovanju prepoznate među utjecajnim obrazovnim institucijama u SAD-u, Europi Južnoj Koreji i Kini. ${ }^{37}$

Tema o primjeni koncepta design thinking u školstvu također je u Hrvatskoj rijetkost, no ipak nalazi prostor na nekim specijaliziranim portalima, npr. u obliku predstavljanja IDEO-vog online slobodno dostupnog priručnika Design Thinking for Educators. ${ }^{38} \mathrm{U}$ popularizaciju koncepta design thinking uključila se i Gradska knjižnica „Ivan Goran Kovačić“ iz Karlovca, koja je o toj temi organizirala predavanje za srednjoškolce u okviru svojeg programa Poslovna knjižnica. ${ }^{39}$

Tema design thinking još je uvijek nepoznanica u hrvatskim knjižnicama, premda su se pojedini hrvatski knjižničari već susretali s njom na inozemnim stručnim skupovima ${ }^{40} \mathrm{U}$ Hrvatskoj je prvu radionicu o primjeni alata design thinking u knjižnicama vodila Dragana Koljenik iz Nacionalne i sveučilišne knjižnice u Zagrebu u okviru 12. savjetovanja za narodne knjižnice u Republici Hrvatskoj početkom listopada $2019 .{ }^{41}$ Tridesetak sudionika iz knjižnica različitih vrsta i veličina prolazilo je metodologiju design thinking radeći u manjim grupama na rješavanju odabranih poslovnih problema svojih knjižnica. Slika 2 prikazuje grupu

\footnotetext{
36 Terziev, S.; M. Obradović. Dizajnersko razmišljanje. // Mreža, prosinac 2018. [citirano: 2019-1115]. Dostupno na: http://www.megatrend.com/wp-content/uploads/2018/11/megatrend-12_2.pdf.

37 Rocco, S. Creative design thinking as a managerial approach. [citirano: 2019-11-15]. Dostupno na: https://bib.irb.hr/datoteka/805676.19commforum-rocco.pdf.

38 Design thinking ili 'dizajnersko promišljanje' u edukaciji. [citirano: 2019-11-15]. Dostupno na: https://www.skolskiportal.hr/clanak/6993-design-thinking-ili-dizajnersko-promisljanje-u-edukaciji/.

39 Design thinking radionica (studeni 1, 2018.). [citirano: 2019-11-15]. Dostupno na: http:// www.gkka.hr/design-thinking-radionica/.

40 Autorica ovog rada sudjelovala je na sesijama i radionicama o primjeni design thinking $\mathrm{u}$ knjižnicama koje su održali predstavnici dizajnerske i savjetodavne tvrtke IDEO na Next Libray Unconference, Aarhus, 17.-18. 6. 2013. i na Future Library Unconference, Atena, 9.-10.11. 2013. Usp. Jones, M. using design thinking to drive innovation in libraries. [citirano: 2019-11-15]. Dostupno na: http://www.nextlibrary.net/group/design-thinking-101.

41 Koljenik, D. Radionica Design thinking za knjižnice. // 12. savjetovanje za narodne knjižnice u Republici Hrvatskoj, Plitvička Jezera, 2. - 4. listopada 2019. [neobjavljena prezentacija]
} 
hrvatskih i slovenskih knjižničara koja je izradila prototip ili inicijalni, opipljiv model rješenja problema neadekvatnog prostora općinske knjižnice u Blatu na Korčuli. Ta je grupa izradila prototip u obliku mreže, a od materijala je koristila raznobojnu špagu. Mreža je predstavljala potrebu knjižnice da se umreži s različitim akterima u lokalnoj zajednici, identificira čvorišta te mreže, odnosno partnere i suradnike kao i usluge koje će dati novu perspektivu poslovanju i daljnjem razvoju knjižnice, npr. u smjeru razvijanja turističkih potencijala zajednice. Ostale grupe za rješavanje svojih poslovnih problema koristile su druge materijale (flomastere, bojice, papir, karton i dr.), a svima je zajedničko bilo ispoljavanje kreativnosti, inovativnosti i zajednički, suradnički angažman u traženju rješenja određenih problema u poslovanju.



Slika 2. Izrada prototipa na prvoj radionici o primjeni koncepta design thinking u hrvatskom knjižničarstvu na 12 . savjetovanju za narodne knjižnice u Republici Hrvatskoj, Plitvička jezera, 2. - 4. listopada 2019. S lijeva na desno: Franciska Jurišić Bačić (Narodna knjižnica Blato), Aleksandra Šutalo i Mirjana Franculić (Gradska knjižnica i čitaonica Požega), Dijana Sabolović-Krajina (Knjižnica i čitaonica „Fran Galovićc“ Koprivnica) i Gorazd Vodeb (Narodna in univerzitetna knjižnica u Ljubljani) ${ }^{42}$

42 Suglasnosti za objavu slike u Uredništvu časopisa. 


\section{Zaključak}

Stephan Bell, ranije spomenuti suautor prve knjige o primjeni koncepta design thinking u američkim akademskim knjižnicama, govoreći o budućnosti design thinking u knjižnicama osvrće se prvo na trenutno stanje. ${ }^{43}$ Navodi da je u proteklih deset godina u knjižničarskim krugovima u svijetu porastao praktični i teorijski interes za tu problematiku. Između ostaloga, svoju tvrdnju ilustrira podacima o velikom zanimanju za trosatnu online konferenciju o načinima uključivanja koncepta design thinking u knjižničnu praksu, održanu 2018. godine na društvenoj mreži Library 2.0, koja se bavi budućnošću knjižnica u digitalnom dobu - registrirano je više od 5000 knjižničara, a na plenarnoj sjednici prisustvovalo je više od tisuću sudionika ${ }^{44}$ Budućnost vidi i u sve većem interesu akademske zajednice, konkretno nastavnika knjižničnih i informacijskih znanosti (Library and information sciences - LIS) za uključivanje filozofije dizajna i metoda učenja design thinking u nastavni plan i program. Smatra da će se s povećavanjem kompleksnosti digitalnog i fizičkog okruženja u kojemu knjižnice djeluju ovaj pristup, usmjeren na razumijevanje potreba korisnika, možda imati veću ekspanzivnu ulogu u području knjižničarstva i trudu knjižničara da pružaju što ravnopravnije iskustvo za sve korisnike knjižnice.

Budući planovi o širenju interesa za primjenu koncepta i metodologije design thinking u hrvatske knjižnice vežu se za uključivanje te tematike u ponudu Centra za stalno stručno usavršavanje knjižničara pri Nacionalnoj i sveučilišnoj knjižnici u Zagrebu te prijevod IDEO-vog priručnika Design Thinking for Libraries na hrvatski. Dragana Koljenik ističe praktičnu korist širenja interesa za design thinking u Hrvatskoj i to za knjižnice, njihove programe, usluge, prostor, sustave. Korist za knjižničare vidi u povećanju kreativnog samopouzdanja, boljem procesu projektnog menadžmenta, jačoj kulturi suradnje i strateškog donošenja odluka. Za korisnike će korist biti u boljoj uključenosti, povećanom zadovoljstvu, novom načinu povezivanja sa zajednicom, dobivanju više knjižničnih zagovaratelja i podupiratelja. Korist za obje strane bit će povećan odgovor na korisničke potrebe, određivanje prioriteta u uslugama i evolucija učinkovitih usluga ${ }^{45}$

\footnotetext{
43 Bell, S. What's next for design thinking in librarianship: from the Bell Tower. // Library Journal, Apr 12, 2018. [citirano: 2019-11-15]. Dostupno na: https://www.libraryjournal. $\mathrm{com} /$ ?detailStory=whats-next-design-thinking-librarianship-bell-tower.

44 Library 2.018 - Design thinking: how librarians are incorporating it into their practice. // Library 2.0. [citirano: 2019-11-15]. Dostupno na: https://www.library20.com/page/design-thinking.

45 Koljenik, D. Nav. dj.
} 


\section{LITERATURA}

Antoljak,V.; M. Kosović. Design thinking za nedizajnere: kako riješiti poslovne probleme i uspješno inovirati. Zagreb: Školska knjiga: Sense savjetovanja, 2018.

Bell, S. What's next for design thinking in librarianship: from the Bell Tower. // Library Journal, Apr 12, 2018. [citirano: 2019-11-15]. Dostupno na: https://www.libraryjournal.com/?detailStory=whats-next-design-thinking-librarianship-bell-tower.

Bartlett, J. A. Design thinking in libraries. // Library Leadership \& Management 34, 4(2018), 1-6. [citirano: 2019-11-15]. Dostupno na: https://uknowledge.uky.edu/libraries_facpub/297.

A branch library builds trust with local teens. [citirano: 2019-11-15]. Dostupno na: $\mathrm{http} / / /$ designthinkingforlibraries.com/teens.

Braun, L. W. Using design thinking: providing a framework for youth activities. // American libraries, ++May 31, 2016. [citirano: 2019-11-15]. Dostupno na: https:// americanlibrariesmagazine.org/2016/05/31/using-design-thinking/

Chase, S. Design thinking in action: changing the public service model. // OLA Quarterly 22, 3(2017), 15-19. [citirano: 2019-11-15]. Dostupno na: https://commons. pacificu.edu/cgi/viewcontent.cgi? article $=1865 \&$ context $=$ olaq

Design thinking for libraries. [citirano: 2019-11-15]. Dostupno na: https://princh.com/ design-thinking-for-libraries/\#.XcqKsjJ7nIU

Design thinking for libraries: examples. [citirano: 2019-11-15]. Dostupno na: http:// designthinkingforlibraries.com/examples

Design thinking for libraries activities workbook: a toolkit for patron-centered design. 1st ed. /San Francisco/: Ideo, 2015. [citirano: 2019-11-15]. Dostupno na: http:// designthinkingforlibraries.com/.

Design thinking in a day: an at-a-glance guide for advancing your library. 1st ed. /San Francisco/: Ideo, 2015. [citirano: 2019-11-15]. Dostupno na: http://designthinkingforlibraries.com/

Design thinking for libraries: a toolkit for patron-centered design. 1st ed. /San Francisco/: Ideo, 2015. [citirano: 2019-11-15]. Dostupno na: http://designthinkingforlibraries.com/

Design thinking ili 'dizajnersko promišljanje' u edukaciji. [citirano: 2019-11-15].Dostupno na:https:/www.skolskiportal.hr/clanak/6993-design-thinking-ili-dizajnersko-promisljanje-u-edukaciji/

Design thinking radionica (studeni 1, 2018.). [citirano: 2019-11-15]. Dostuno na: http:// www.gkka.hr/design-thinking-radionica/

Johannsen- Sköldberg, U; J. Woodila; M. Çetinkaya. Design thinking: past, present and possible futures. // Creativity and Inovation Management 22(2013), 121-146. 
Jones, M. Using design thinking to drive innovation in libraries. [citirano: 2019-11-15]. Dostupno na: http://www.nextlibrary.net/group/design-thinking-101.

Koljenik, D. Radionica Design thinking za knjižnice. // 12. savjetovanje za narodne knjižnice u Republici Hrvatskoj, Plitvička Jezera, 2. - 4. listopada 2019. [neobjavljeno izlaganje]

Leuzinger, R.; G. Kessler Lee; I. Korbe. Keeping up with... design thinking. // American Library Association. [citirano: 2019-11-15]. Dostupno na: http://www.ala.org/acrl/ publications/keeping_up_with/design.

Library 2.018 - Design thinking: how librarians are incorporating it into their practice. // Library 2.0 [citirano: 2019-11-15]. Dostupno na: https://www.library20.com/page/ design-thinking.

Meier, J. J. ; R. K. Miller. Turning the revolution into an evolution: the case for design thinking and rapid prototyping in libraries. // College \& Research Libraries News 77, 6(2016), 283-286. Dostupno na: https://doi.org/10.5860/crln.77.6.9506.

Oluja mozgova: enciklopedijski članak. // On-line izdanje Hrvatske enciklopedije Leksikografskog zavoda Miroslav Krleža. [citirano: 2020-01-15]. Dostupno na: http://www.enciklopedija.hr/natuknica.aspx?ID=45089.

Østergård, M. Dokk1 - Re-inventing space praxis: a mash-up library, a democratic spa$c e$, a city lounge or a space for diversity? // Library design for the 21 st century: collaborative strategies to ensure success / ed. by Koen, Diane, Lesneski, Traci Engel. Berlin; Boston: De Gruyter Sauer, 2019. Str. 91-103.

Rocco, S. Creative design thinking as a managerial approach. [citirano: 2019-11-15]. Dostupno na: https://bib.irb.hr/datoteka/805676.19commforum-rocco.pdf.

Rum til forandring - Dokk1-Aarhus'nye mødested = Space for change: Dokk1 - Aarhus new meeting place / editorial board Rolf Hapel, Knud Schulz, Marie Østergard, Kim Holst Jensen. Aarhus: Aarhus Kommunes Biblioteker, 2015.

Terziev, S.; M. Obradović. Dizajnersko razmišljanje. // Mreža, prosinac 2018. [citirano: 2019-11-15].

Dostupno na: http://www.megatrend.com/wp-content/uploads/2018/11/megatrend-12_2.pdf. 